\title{
Tsubouchi, Dryden and Global Shakespeare
}

\author{
Daniel Gallimore \\ Kwansei Gakuin University, Japan \\ gallimore@kwansei.ac.jp
}

\begin{abstract}
What does it mean for Shakespeare's plays to be recognized as both 'universal' and 'foreign' in a recipient culture? In the case of Japan, where Shakespeare was initially received in the late nineteenth century, one answer might be that Japanese Shakespeareans have adopted a kind of 'soft humanism'; in other words one not specifically situated against the horizon of the English Renaissance, but instead fulfilling a range of purposes within the local culture, not least the touting of 'universal' values. Universals appeal to societies perceived to lack a strong awareness of the individuated self, such as in late nineteenth century Japan, where the pioneering Shakespeare translator Tsubouchi Shōyō was among the first to encounter Shakespeare's works. One influence on Tsubouchi's translating style that is often overlooked is that of John Dryden, who becomes a central figure in the history of English literature which Tsubouchi published in 1901. Like Dryden, Tsubouchi finds in Shakespeare a forum for philosophical and ideological exchange; Dryden may well have provided Tsubouchi with a critical perspective on their predecessor. This article discusses their relationship with regard to Dryden's influential adaptation of Antony and Cleopatra, All for Love (1678), and Tsubouchi's 1915 translation of the same play.
\end{abstract}




\section{Tsubouchi and Shakespeare's Translations in Japan}

Translation is an anonymous business, but in some cases translators may acquire some of the cultural authority reserved for original authors. We think of how the names of North and Golding have become almost synonymous with their Plutarch and Metamorphoses, and recognize their privileged role in introducing two prominent classical texts to the Elizabethan reading public. No one is likely to confuse the translator with the original author but, for many readers, the translator may exercise a distinct monopoly over what the author originally meant, greater even than any academic specialist (which the translator may also be), and this is a position that can create problems as well as opportunities. In the case of Tsubouchi Shōyō (1859-1935), whose translation of the Complete Works was itself completed in 1928, the imposition of Shakespeare's cultural authority is compounded by the cultural and linguistic distance between the source and recipient cultures, not to mention the complex historical moment at which the translations were completed.

Tsubouchi translated Shakespeare at a time of profound social crisis in Japan which was changing from a feudal to a modern state- when the existing patriarchy was to some extent fused with Western cultural models in the public personae of the fathers of Japanese modernization. It is somewhat inevitable, therefore, that Tsubouchi should have earned a reputation as the father of Japanese Shakespeare studies, as well as of the modern Japanese novel and of Japanese comparativism. Yet Tsubouchi himself insisted that his love for Shakespeare could never be properly reconciled with his strict Confucian upbringing as the son of a samurai, and while there is no doubting his status as a pioneer, Tsubouchi's sense of discrepancy is also reflected in the difficulties he had in appropriating Shakespeare and in a general theoretical observation that far from being an original procreator, he is -like North and Golding- engaged in a diffuse and highly creative process that extends from Shakespeare through Tsubouchi and onto the plays' reproductions in contemporary Japan. In order to prevent his own position from being idealized out of proportion to his actual authority, it is hardly surprising that Tsubouchi should have taken an interest in the work of other participants in the history of Shakespeare's making, each of them offering critical perspectives against which Tsubouchi could measure his own perspective. As a scholar and translator, it would have been surprising if he had not read the relevant critics. This article explores one such relationship that may have been of particular relevance and importance to Tsubouchi, namely with the English poet, dramatist and translator John Dryden (16311700). Both Tsubouchi and Dryden were highly educated individuals who stood at the threshold of new national literatures and who knew more than they perhaps cared to know about how the historical accretion of meanings can create a world literature out of a local literature: Dryden as a translator of The Aeneid and Tsubouchi for his deep knowledge of his native literature and eventually for his Shakespeare translations.

Tsubouchi discovered Dryden along the road of the writer's quest for historical continuity. As a young writer in the 1880 s, Tsubouchi wrote political lampoons for the popular press followed by a series of novels, adopting a comic, satirical style from the 
gesaku or 'low life' novelists of eighteenth and nineteenth century Japan. At the same time, beginning at university, Tsubouchi was reading and sometimes translating British writers such as Shakespeare and Sir Walter Scott, and becoming increasingly dissatisfied with what he regarded as the two-dimensional characterizations of his native fiction. Tsubouchi is still regarded by some as a comic genius (Tsuno, 2002) -as someone who never failed to smile at the limitations of himself and of others- and in coming to translate Shakespeare, it was for his comic effects that he depended first and foremost on his native fiction.

Yet if comedy was Tsubouchi's talent, the psychological depth of his translations and other work is derived from a cognitive awareness of his own historical role against the context of English literature. This is indeed a critical minefield but, to start with, three points may be made. The first, as Ueda Atsuko has convincingly argued (Ueda, 2007), is that in rejecting gesaku fiction as he did in his highly influential treatise on fiction Shōsetsu shinzui ("The essence of the novel", 1885), Tsubouchi was discretely disassociating himself from the Freedom and People's Rights Movement that achieved some success in the 1880s in its campaign for an elected national assembly, but never achieved its ultimate goal of full democracy. The Meiji Constitution of 1889 enfranchised only males paying substantial property taxes, thus excluding the class of literate craftsmen and minor samurai to whom one of the greatest of gesaku writers Takizawa Bakin (who died in 1848) had addressed his tales of urban life. Bakin was one of the literary mentors of the Freedom and People's Rights Movement (Ueda, 2007: 64-68), and he was also a writer whom Tsubouchi had enjoyed in his youth, but it was through the humanism he absorbed in his study of English literature at university and beyond that Tsubouchi came to reject such writers. Bakin's stories were intended partly for communal recitation, whereas the new literature that Tsubouchi was conceiving was essentially a private experience.

Having rejected gesaku fiction for its didacticism and frankly pornographic tendencies, Tsubouchi also realized its dramatic potential for the purposes of satire and impersonation. In other words, if (as is remarked) literary translation is a form of parody, Tsubouchi's literary voices may have proved extremely useful allies in his ambitious project of developing a truly three-dimensional modern Japanese novel, and of translating Shakespeare. Despite the ambitious plots of his novels, he was never able to achieve the depth of interiority of the younger generation that emerged in the 1900s. But when he translated Shakespeare in the rather different cultural climate of Taishō Japan, Tsubouchi was of course guided by Shakespeare's style, as well as various literary and linguistic influences, into developing a hybrid literary and colloquial style.

The second point is the difficulty Tsubouchi faces in historicizing Shakespeare. In the prefaces that Tsubouchi wrote to each of his Shakespeare translations, aside from standard information about the plays' sources and critical history, Tsubouchi shows himself to be primarily interested in stylistic and generic comparisons with his native literature rather than in any rigorous historical comparison between Shakespeare's age and his own, and in contrast to contemporary translators, he includes lengthy stage directions but no footnotes. In this regard, he is no different from the Western editors 
such as Kenneth Deighton and W.J. Rolfe, on whose editions he depended, but while admitting a spiritual response to the plays, Tsubouchi is unable to specify the nature of that response, for example in the terms of Zen 'awakening' (or satori), and following the Victorian critic Edward Dowden, he cautions against the perils of probing too deeply into Shakespeare's "multifarious" mind. ${ }^{1}$ Tsubouchi's reservations pitted AngloSaxon empiricism against the aesthetic idealism of Ernest Fenollosa, whose lectures at the Imperial University he had attended (and had criticized), and at a time when Japanese ideologues were seeking rationalist approaches to the various problems that confronted them. Tsubouchi himself was never part of the political establishment, but in his early career at least was surely at one with the suppression of religions outside State Shinto, in particular of Buddhism and Christianity, implemented by the Japanese government in the 1890s. In ignoring Shakespeare's context, Tsubouchi was no doubt guilty of ignoring his own.

A third contradiction, as I have mentioned, lies in the issue of fatherhood. According to the iemoto system that legally governed domestic life until 1945 and which still functions within the traditional arts including kabuki and the tea ceremony, the father was granted extraordinary powers to ensure that the spiritual and physical properties of the family were passed to the next generation and properly maintained. Tsubouchi never sought to initiate a school of Shakespeare translation, although he had his numerous pupils at Waseda University, and in 1905 initiated the Bungei Kyōkai (Literary Arts Association) that became responsible for staging the first complete productions of Shakespeare plays in Tsubouchi's own translations. The problem was that unlike kabuki and the tea ceremony, which have relatively fixed traditions derived from native culture and religion, Tsubouchi was dealing from the start with a commodity that was foreign and, by his own admission, mysterious. Incidentally, Tsubouchi and his wife, being unable to have children of their own, adopted two sons from among his siblings together with the daughter of a friend, which was and remains common practice in kabuki families when suitable heirs are lacking.

Tsubouchi seems to place himself above politics, beyond history, and even outside the expectations of his class and educational background in his attempt to do justice to Shakespeare, but if we apply the view of contemporary translation theory that translators can never do justice to their counterparts, because a translation that is equivalent to its source is not a translation, then the idealized view of Tsubouchi starts to unravel, and we realize how his response to Shakespeare is shaped by his own diffuse influences.

\section{Two Restoration writers}

Tsubouchi's relationship to kabuki drama has been thoroughly chronicled by those wishing to assert a specifically 'Japanese' or 'Japanised' Shakespeare, but in this article I propose to explore his relationship with an English writer who, as Satō Isao has demonstrated (Satō, 1981), may well have provided Tsubouchi with the perspective that 
his idealized position so badly required. Like Tsubouchi, John Dryden was a translator and a devotee of Shakespeare, albeit not without reservations, and like Tsubouchi lived in an era of social change. ${ }^{2}$ It is significant, for example, that Tsubouchi's first attempt at literary translation was of part of Scott's The Bride of Lammermoor (1819), published at the age of twenty with a university friend. Scott too was interested in the period which preceded the Jacobite rebellion of 1715, and was interested enough in Dryden to publish an edition of his dramatic works together with a short biography.

It is likely that Tsubouchi first encountered Dryden's works as a student in the late 1870s at the Imperial University in Tokyo. Tsubouchi himself majored in political science, and was something of an expert on British constitutional history, but his literary interests and friendships ensured that he also took courses in English literature, and so acquired a grounding in English literature, above all Shakespeare. As his reading intensified during the 1880s, Tsubouchi would have become aware of Dryden's view of Shakespeare, and perhaps may have identified with Dryden's role as an early mediator of taste and convention in the literary circles of Restoration England. Yet Tsubouchi also took a more direct interest in Dryden in a history of English literature, Eibungaku shi, which includes a substantial section on Dryden, and then in a work on English poetry published the next year (Tsubouchi Yūzō, 1902), he produced a translation of Dryden's ode “Alexander's Feast" (1697). ${ }^{3}$ After that, Tsubouchi's interests became focused on Shakespeare translation and his own creative writing, but towards the end of his life, Tsubouchi published a pageant based on ancient Japanese history called Shōtoku Taishi to akuma ("Prince Shōtoku and the Demon") (1935), which was conceived as a new Japanese oratorio using the poetic format of Dryden's ode. There were obvious historical parallels with Alexander the Great as well, since Tsubouchi's pageant was about the man who is reputed to have devised Japan's first constitution in the early seventeenth century and the first to have called his country Nihon, "the land of the rising sun".

Like many of Tsubouchi's experiments, Shōtoku Taishi was innovative for its time, but has now been forgotten, probably because it relied so much for its effect on kabuki techniques without being actual kabuki drama. Tsubouchi's Shakespeare translations have been criticized for the same reason, but there was always a need for Shakespeare in Japanese, which at first only Tsubouchi was positioned to fulfill. What is fascinating about Tsubouchi's encounter with Dryden, however, and in particular with "Alexander's Feast", is that it should so precisely express Tsubouchi's literary concerns at this time, in particular his relationship with Shakespeare.

Tsubouchi's relationship with Shakespeare is threefold, and in all respects quite similar to Dryden's. First of all, Shakespeare is 'the poet of nature', whose representation of nature is too profound to admit deep critical analysis. Secondly, Shakespeare is structurally complex; in this regard, Tsubouchi admitted that he started to understand Shakespeare only when he translated the one play that obeys the unities of time and place, The Tempest. Finally, Shakespeare embraces a linguistic and rhetorical range that poses a special challenge for Japanese translators. Tsubouchi had none of Dryden's qualms about Shakespeare's failure to rhyme, since meaningful 
rhyme is almost impossible in Japanese, but at the same time his difficulty with Shakespeare may be merely another expression of Dryden's difficulty in appropriating Shakespeare to the new age. In An Essay of Dramatic Poesy, Dryden expresses famously mixed feelings about Shakespeare, castigating him on the one hand for his incoherent plots and lack of sense, but then declaring that:

He was the man who, of all modern and perhaps ancient poets, had the largest and most comprehensive soul. All the images of nature were still present to him, and he drew them not laboriously, but luckily. When he describes anything, you more than see it, you feel it too. Those who accuse him to have wanted learning give him the greater commendation. He was naturally learned. He needed not the spectacles of books to read nature. He looked inwards, and found her there. (Dryden 2003: 110)

Likewise, Tsubouchi felt that Shakespeare had certain qualities that demanded preservation. Shakespeare had a natural appeal for Tsubouchi's society, as it promoted literacy for all and sought to escape from a rigid feudal hierarchy that had distinguished a small élite educated in the Chinese classics. Tsubouchi belonged to both the educated élite and the 'rising generation', and his translations, cheaply produced in the 1910s and 1920s in individual volumes, were undoubtedly intended to bridge the divide.

Tsubouchi made a series of forays into Dryden throughout his career, which would bring him back repeatedly to Shakespeare, but it is significant that his translation of "Alexander's Feast" was published in the same year that Tsubouchi was firing the first shots in his famous literary dispute (botsuri ronsō, or "concealed ideals dispute") with the writer and Goethe translator Mori Ögai, which was to cover much the same thematic ground as his previous critique of Fenollosa. Roughly speaking, Tsubouchi espoused a realist view of literature, different from Ōgai's idealist one, asserting that the relentless pursuit of ideals entailed a dangerous loss of identity; this dispute had important repercussions in the early years of the next century, with the rise of proletarian literature and the 'I novel'. In an essay published in 1891 (Tsubouchi, 1978 b), the same year as his translation of "Alexander's Feast", referred to Shakespeare's imagination as "a bottomless lake", within which any who dared venture would be drowned; ${ }^{4}$ one observes a similar hint of danger in the tale of "Alexander's Feast".

Dryden's ode tells the true story of a feast that Alexander held following the defeat of the Persian king Darius at Persepolis in 331 B.C. As Alexander becomes gradually more intoxicated, his bard Timotheus sings songs on his lyre that lead the conqueror through a series of powerful emotions: first praising him as a god, then of the pleasures of wine, then of the sad death of the brave Darius, then of the beauty of Alexander's lover Thäis, and finally of anger at the deaths of Alexander's soldiers, driving Alexander to destroy the Persian palace (although without further loss of life). Dryden's ode, subtitled “The Power of Music", written for St Cecilia's Day, 22 November 1697, and set to music first by Jeremiah Clarke and in 1736 by Georg Friedrich Handel, implied a Christian message also of the power of music within an ecclesiastical context. As the final stanza proclaims: 
At last divine Cecilia came, Inventress of the vocal frame;

The sweet enthusiast, from her sacred store,

Enlarge the former narrow bounds,

And added length to solemn sounds,

With nature's mother-wit, and arts unknown before.

Let old Timotheus yield the prize,

Or both divide the crown;

He raised a mortal to the skies,

She drew an angel down.

(Dryden, 2003: 550)

Alexander does not drown in "the bottomless lake", but he does suffer a loss of dignity that goes as far as the wine and music will take him. In choosing to translate this poem, Tsubouchi is assenting that music, as indeed all artistic forms, retains a natural prerogative to move audiences, and that a little loss of dignity -by releasing suppressed emotions- can do no harm. Art may therefore play its part in shaping history; a writer of Shakespeare's scope may well shake the dignity of both his English and Japanese successors.

Dryden's narrative verse, with its rotund rhymes and dignified tetrameters, is not exactly Shakespeare's, but it is indicative of the style of a great writer who comes after Shakespeare, just as Tsubouchi can only translate Shakespeare in a style that is not Shakespeare's own. In fact, Tsubouchi's translation of the verse recalls some of his most famous Shakespeare translations, for example of Ariel's song "Full fathom five", where the Shakespearean lyric comes close to the lyricism of the traditional syllabic Japanese pattern with which Tsubouchi was most familiar. ${ }^{5}$ Tsubouchi's translation of Dryden (1902: 137-139) is not purely syllabic, but it does share the gravity of the original:

\author{
kakute tsui ni kano fükin no kaisotaru \\ josei Shishiriya koso idemashikere \\ kono myōon no nesseisha sono ito tōtoki chinō wo shibori \\ semakarishi hani wo hiroge \\ itomo kedakaki raku no ne ni doryō wo kuwaeta maikeri \\ zōka no kami ga honzanchi mata mizochi no myōku mote \\ Chimoshüsu no sao wo shite shō wo yuzurashime yo \\ sanakuba meiyō no kanmuri wo nisha byōdō ni wakatashimeyo \\ kare wa ningen wo amatsu sora made nobaraseki \\ kore wa amatsu hito wo orikosaseki
}

\title{
3. The effects of Hippolyte Taine
}

Dryden is also important to Tsubouchi in his attempts to frame a critical methodology for the study of English literature, and thence in understanding his role as a Shakespeare 
translator. Reproaching the superficiality of his native Tokugawa fiction, Tsubouchi's early Shōsetsu shinzui had emphasized the primacy of "human feeling" to the novel's purpose above "social customs", 6 arguing that for the writer the most important conventions are not social but literary, though genres could of course be derived from customs. In the twenty or so years following Shōsetsu shinzui, Tsubouchi had the opportunity to make a more systematic study of English literature, in particular to examine the Tainean assumptions that lay behind his approach. Hippolyte Taine's Histoire de la littérature anglaise ("History of English Literature", 1863-64) was published in English translation in 1871, being listed in the bibliography of Tsubouchi's own Eibungaku shi (1901). Taine's relevance to Tsubouchi is all the more significant when one considers the influence of Tainean historicism on other late Victorian critics that Tsubouchi read, such as William Swinton, Edward Dowden and Richard G. Moulton; Tsubouchi was merely trying to work out a more credible theoretical basis to his literary studies than had previously been available.

What Tsubouchi was after was an understanding of literary history that could be appropriated to his own Buddhist awareness of the relations of cause and effect (inga kankei). Tsubouchi was not a religious man, but this awareness is so fundamental to Japanese aesthetics, to kabuki for example, as it was to his education, that he could hardly have ignored it. Although it was not until the 1930s that the Japanese philosopher Nishida Kitarō (1870-1945) developed a theory of the historical world to match Hegel's, Tsubouchi was able to grasp the underlying currents of literary history in terms of race, circumstance and epoch in Taine's positivism:

Man, forced to accommodate himself to circumstances, contracts a temperament and a character corresponding to them; and his character, like his temperament, is so much more stable, as the external impression is made upon him by more numerous repetitions, and is transmitted to his progeny by a more ancient descent. So that at any moment we may consider the character of a people as an abridgement of all its preceding actions and sensations; that is, as a quantity and as a weight, not infinite, since everything in nature is finite, but disproportioned to the rest, and almost impossible to lift, since every moment of almost infinite past has contributed to increase it, and because, in order to raise the scale, one must place in the opposite scale a still greater number of actions and sensations. Such is the first and richest source of these master-faculties from which historical events take their rise; and one sees at the outset, that if it be powerful, it is because this is no simple spring, but a kind of lake, a deep reservoir wherein other springs have, for a multitude of centuries, discharged their several streams. (Taine, 1887: 24)

In Taine's conception, the nature of Shakespeare's genius is to lighten a little the weight of history. Shakespeare is both a product of history and a response to it, and it is because that response is comprised of a vast array of instinctual "actions and sensations" Shakespeare himself is as unknowable (or "bottomless") as his historical background is knowable. Any attempt to get to the 'bottom' of Shakespeare's mind and art is as doomed as trying to rationalize one's own instincts. A translation, however, can never leave as remarkable an imprint as an original work, because whatever literary 
qualities it may possess, it will always come after that unique moment for which the original was intended. In other words, the grounds for a translation's reception are established just as fully as those of an original literary work, even if "the total effect is different" (Taine: 25).

Taine presented cultural change as a process of actual happening with its own internal momentum; this theory surely appealed to Tsubouchi as he sought to distance himself from predetermined ideas and ideals (including those of Christianity). Nishida went rather further than Taine in insisting on "a continuity of discontinuities" in human experience: human beings interact to create their own world, but because they do so from different perspectives, there can be no linear, universal goal of creation, only "absolute present" (Moraldo, 2010). Nishida's categories are relevant to this context in that it suggests that the object of Shakespeare translation in early twentieth century Japan was nothing as banal as Japanese imperialism, but rather the recreation of Shakespearean poiesis, or what Nishida terms "action-intuition" (Moraldo, 2010). Writers respond intuitively to any given situation, creating both themselves and their work through their response; it is clear that both Dryden and Tsubouchi are fascinated by Shakespeare's gifts of "action-intuition". Although Nishida does not attempt to construct a critique of judgment, the goal of all conscious experience according to his philosophy -and especially Zen meditation - is one of absolute nothingness, a state where all contradictories are held in perfect balance and which by its nature excludes transcendent universals. If this state is realized as one of profound aesthetic content, as a sanctuary for the restless mind, then that may also amount to what Tsubouchi discovered in Shakespeare, and to what John Dryden glimpsed as he sought to bridge the gap between his own 'barbarian' age and the classics.

\section{4. "A kind of pleasantly hazy golden aura": the romanticism and nihilism of Antony and Cleopatra}

The Shakespeare play that deals most explicitly with nothingness is King Lear (1608), but Antony and Cleopatra (1606) is another late tragedy that plays on an erotics of nothingness: where the might of Rome is dismissed as inconsequential through the force of the lovers' rhetoric, where that same rhetoric is speedily overcome by Octavius "both by sea and by land", and where finally the suicides of Antony and Cleopatra are conceived in erotic terms. Enobarbus has the measure of both Cleopatra and the play as a whole when he declares:

Under a compelling occasion let women die. It were pity to cast them away for nothing, though between them and a great cause they should be esteemed nothing. Cleopatra catching but the least noise of this dies instantly. I have seen her die twenty times upon far poorer moment. I do think there is mettle in death, which commits some loving act upon her, she hath such a celerity in dying. (1.2.130-137) 
In addition to the bawdy Shakespearean innuendoes of "death" and "nothing", Enobarbus' words contrast his own realism -his belief that women achieve nothing in the world- with the erotic, that is to say, generative power of death to make those still living aware of their remaining vitality, and thus sexuality as well.

Romantic love in Shakespeare is beautiful because it amounts to "nothing", which in the comedies is signified by the empty circle of the wedding ring and in the tragedies made real by the nothingness of death. What is universal about the experience is the fact that if any love could claim a truly enduring power in itself (other than by procreation), then it could no longer be grasped as universal by those outside the relationship. It is surely this sense of transience for which one searches, among other things, in testing Shakespeare's global appeal.

One justification of this appeal presents itself in the conspicuous need of Dryden and his contemporaries to adapt or rewrite this play so imbued with transience. In other words, adaptation is just one means of recovering emotions once so deeply felt, even if the original effect cannot repeat itself. As Dryden writes in the preface to his own All For Love, or The World Well Lost, first staged in 1678:

The death of Antony and Cleopatra is a subject which has been treated by the greatest wits of our nation, after Shakespeare; and by all so variously, that their example has given me the confidence to try myself in this bow of Ulysses amongst the crowd of suitors, and, withal, to take my own measures, in aiming at the mark. (Dryden, 2011:32)

Following the classical precedent, the challenge of "the mark" is to present "the hero of the poem" not as "a character of perfect virtue, for then he could not, without injustice, be made unhappy; nor yet altogether wicked, because he could not then be pitied." Finally, the pleasure of the drama lies in "the excellency of the moral": that the love of Antony and Cleopatra is transient and not allowed to endure, and that they are punished for their "wholly voluntary" "crimes of love". Dryden's classically moralistic viewpoint does not, therefore, have to detract from the transient beauty of the play, nor from what Dryden perceives to be its most readable qualities: its unity of action and the purity of Shakespeare's dramatic poetry. For Dryden, this is a play in which everything comes to a piece; all that he has to do is to compress Shakespeare's tragedy to its natural space of two or three hours' traffic on the stage, in other words, to apply the unity of time.

Whereas modern audiences might see Cleopatra as an Oriental woman, as mysterious in her sexuality as the tracts of unconquered Asia that lie beyond her, Dryden sees her love for Antony as ultimately transgressive, and her various transgressive gestures leading irrevocably to the play's tragic end. Dryden is in no doubt as to the universal meaning of the drama, but it is a viewpoint based on Roman rather than Oriental values. As Shakespeare's most Oriental play, as the play which makes the clearest distinction between east and west, it is strange that Antony and Cleopatra has made relatively little impression in Japan. ${ }^{7}$ In the 1880 s, the Meiji statesman Fukuzawa Yukichi had argued that Japan should distance itself from its cultural roots in east Asia, as it sought to emulate the Western powers, and this was a policy that Japan followed by imperialist means, annexing first Taiwan in 1895 and 
then Korea in 1910. For Edward Said, the Orient began in Alexandria and Constantinople, and in his famous book (Said, 1995), seldom extends beyond India. Japanese academics and diplomats of Tsubouchi's generation would have adopted the Western categories, with the word tōyo (literally, "the Eastern seas") being equivalent, as it is now, to Said's "Orient". Yet Japan's cultural affinity was with China and Korea (later redefined under colonialism), to a lesser extent with India, but hardly at all with Egypt or Turkey. If the ooze and slime of Shakespeare's play struck any chord with the likes of Tsubouchi, it could not have been for its Orientalism.

The play that was rather more obviously 'Oriental' for Tsubouchi's contemporaries, and which was translated into Japanese as early as 1909, was Oscar Wilde's Salomé (1894). Salomé's Dance of the Seven Veils before Herod Antipas is dramatically similar to the dances of young women in various $n \bar{o}$ and kabuki dramas, although it is the play's thematic mix of filial loyalty, bloody revenge and sexual attraction leading Salomé to dance in exchange for the head of the prophet Iokanaan (John the Baptist) that must provoke the strongest comparison. By contrast, Cleopatra's dual role as queen and whore is strikingly absent from kabuki, although the suicides of the two lovers do recall the motif of double love suicide (shinjū) in kabuki sewamono (domestic dramas), even if only in the way that their deaths become the focal point of the tragedy. In kabuki, such suicides are highly ritualized, whereas in Antony and Cleopatra, the two lovers (and especially Cleopatra) create their own ritual of death as they seek to resist an external force, the army of Octavius Caesar. In kabuki also, the lovers (usually both young and anonymous) are escaping strict laws against illicit relationships. Yet because they are engaged in an unwinnable game, in which the sympathies of the original seventeenth and eighteenth century audiences would have been definitely pitched in their favour, their role becomes mainly to fulfill social expectations. They walk and dance the customary michiyuki (or stylized journey) for a dawn rendezvous in a secluded spot outside the town, where facing west (the direction of the Buddhist "Pure Land") and with their backs turned to the rising sun, they deliver final statements on the transience of life through a narrator, before the man disembowels himself with a long knife and the woman cuts her throat with a shorter one.

In Antony and Cleopatra, by contrast, the lovers have lost at a game that they might once have won, so that their suicide becomes a final validation of the same romanticism that has destroyed their chances of victory; having failed to save themselves from defeat by Octavius, they can at least save themselves from whatever humiliations Octavius has in store for them. Unlike the kabuki lovers, it is important that the two be seen to be acting independently, and since Cleopatra is the undeniable source of the play's romanticism, it is left to her to mastermind the play's conclusion. The two protagonists are not simply the victims of their own undoing, but have enough free will to make themselves attractive to Dryden and the other moralists. The tragedy of Antony and Cleopatra is in this sense subtly different from Shakespeare's other great tragedy of crossed love, Romeo and Juliet (1595), where the lovers are at once betrayed and sanctified by their innocence, and from kabuki sewamono, where a recognizable system of oppression serves both to deepen and crush the bonds of erotic love. 
Meiji intellectuals such as Tsubouchi inherited numerous models of romantic love from their own tradition, stretching back through kabuki and gesaku fiction to The Tale of Genji in the eleventh century. Yet in the terms of Taine's argument, the opening of Japan to Western influence during the second half of the nineteenth century created a new and unprecedented set of "circumstances" that were bound to influence notions of romantic love. In this context, the translation by Tsubouchi's pupil Shimamura Hōgetsu of Ibsen's A Doll's House (1879) for production in 1911 by the Bungei Kyōkai, is obviously important in presenting a 'circumstance' that was exactly the opposite of traditional Japanese norms. As I have suggested, Tsubouchi was always to some extent torn between adherence to those norms and a modern fascination with the potential of dramatic art. When Hōgetsu and the company's leading actress Matsui Sumako, who had played Ibsen's Nora, left their respective spouses to have an affair with each other and form their own company, Tsubouchi had little choice but to dissolve the Bungei Kyōkai. Sumako killed herself in 1919 shortly after the death of Hōgetsu from influenza, and so having translated Antony and Cleopatra four years before this tragic finale, it is interesting to consider how Tsubouchi may have viewed a play that seemed to reflect with painful clarity what had been going on around him. Since Tsubouchi disapproved of the affair, he might have agreed with Octavius (and Dryden) that:

High events as these

Strike those that make them, and their story is

No less in pity than his glory which

Brought them to be lamented.

(5.2.354-357)

Yet the deaths of Hōgetsu and Sumako were still to come, and instead it is more likely that the play accorded with an enduring romanticism within Tsubouchi's temperament that was itself at odds with the realism and naturalism of Taishō culture. ${ }^{8}$ In his preface, he refers to Dowden's assessment ${ }^{9}$ that:

if Julius Caesar is like an ancient Greek sculpture, unyielding in the precision with which it details military and ceremonial matters, this work is an exceptional final flowering of the Renaissance, almost overburdened with the weight of its abstractions, a play of instinctive appeal to its audiences, unsettling the blood, captivating the imagination, infused with a kind of pleasantly hazy golden aura that arises from the male and female protagonists of the play, at times like the fantasies one knows from one's dreams, and at times possessed of a splendour that transcends reality. (Tsubouchi, 1934: iii-iv)

Tsubouchi later comments that the protagonists appear more "demi-gods" than human beings, shifting the generic balance towards "six parts romanticism and four parts naturalism", whereas he had elsewhere observed that Shakespeare was commonly five parts realism to five parts fantasy. ${ }^{10}$ This rejoinder is sufficient to suggest that the play held a special meaning for Tsubouchi, even if he found "the subtle music of its poetry" (ibid.: xi) difficult to render in Japanese prose. A further indication of what the play 
may have meant to Tsubouchi comes in the quotation of what is Cleopatra's second line in the play on the fly leaf of the original pocket edition (1.1.16):

I'll set a bourn how far to be beloved.

Watasha dono kurai ai sarete iru no ka, sono ai no hani ga shiritai.

Significantly, Tsubouchi translates the phrase "I'll set a bourn" with one that literally means "I want to know the extent of that love". "While underscoring the dramatic irony of the original, albeit less playfully, Tsubouchi makes a strikingly modern suggestion that Cleopatra is a serious romantic character, driven by a need to know the nature of love. Moreover, having previously translated King Lear in 1912, Tsubouchi must have been aware of the proximity of Cleopatra's challenge, "If it be love indeed, tell me how much." (1.1.14, which the quoted line follows), to Lear's question to his daughters, "Which of you shall we say doth love us most" (1.1.51). Yet whereas Lear is blinded by self-love, Cleopatra's challenge is at once inspired and calculating. Antony and Cleopatra must have seemed to Tsubouchi to have had the human qualities that King Lear so painfully lacked, although we know that it was the later tragedy that he wanted his contemporaries to see (Shōyō Kyōkai, 1986: 284).

Tsubouchi's sense of the romanticism of Antony and Cleopatra is also reflected in the play's unusual structure. The defeat of the two lovers in Act 3 allows the lovers time in which to dramatize both their deaths and their feelings for each other as a counter to the comedy of what has come before. This device of reducing the pace almost to real time is similar to a technique Tsubouchi uses in his own historical dramas, such as Kiri hitoha ("Fallen paulownia leaves", 1894), where dramatic tension is accumulated and prolonged in the expectation of a known and imminent outcome, namely the fall of Osaka Castle in 1615 and the destruction of the house of Hideyoshi. This tension also corresponds with Dryden's observation that:

the action is so much one, that it is the only one of the kind without episode, or underplot; every scene in the tragedy conducing to the main design, and every act concluding with a turn of it. (Dryden, 2011: 32)

For Dryden, there is little to distract from the tension of the dramatic line. For Tsubouchi, however, the unity of action may be more of a hindrance than a help, since the sheer number of scenes in the third and fourth acts, not to mention all the unfamiliar classical names, would have confused Japanese audiences used to kabuki scenes of one hour or more, and he therefore recommended that in Japanese the play be read rather than performed (Tsubouchi, 1934: v).

\section{Conclusion}

For both Dryden and Tsubouchi, the romantic theme of Antony and Cleopatra gives it a powerful universal appeal, albeit one in which they would not have wanted to be 
engaged themselves. Both writers approach this middle-aged play from the hindsight of middle age; Shakespeare was about 42 when he wrote it, Antony is past 40, Dryden 48, and Tsubouchi 57. Dryden and Tsubouchi also approach the play during periods of fundamental transition in their societies. Enough is known of Restoration London, but Tsubouchi's Tokyo was also a community in which newly rich entrepreneurs, and even the not so rich, could afford to take advantage of their domestic authority to engage mistresses. For Dryden and Tsubouchi, therefore, the universality of Antony and Cleopatra lies not in the prerogative of romantic love, but in the power of the artistic imagination to effect subtle psychological changes. Romantic feeling is but one example of those changes, and in the case of Antony and Cleopatra provokes the interesting question of how far one can go, the limit of love's bourn. This is also a question for Dryden and Tsubouchi as translators, as they each in their own way wonder how far they can take their respect and enthusiasm for the source text. As Dryden writes with regard to Ovid:

No man is capable of translating poetry, who besides a genius to that art, is not a master both of his author's language, and of his own. Nor must we understand the language only of the poet, but his particular turn of thoughts, and of expression, which are the characters that distinguish, and as it were individuate him from all other writers. When we are come thus far, 'tis time to look into ourselves, to conform our genius to his, to give his thought either the same turn if our tongue will bear it, or if not, to vary but the dress, not to alter or destroy the substance. (Dryden, 2003: 163)

Tsubouchi is equally as confident in his capacity to translate Shakespeare, and like Dryden that confidence is derived from the translator's caveat that no translation can be perfect, or rather that it is to the credit of both Shakespeare and Ovid that their work can be translated at all. For Tsubouchi, the problem of Shakespeare's universality does not have to be a problem, especially if his notion of the incomprehensibility of Shakespeare's consciousness is another way of saying that when Tsubouchi asserts or recovers his individuality through the act of translation, then Shakespeare's consciousness, and all its historical accretions, will gradually absent themselves, and Tsubouchi will be left with the nihility that he desires. For Dryden also, Shakespeare may be the exception that proves the rule.

\section{Notes}

1. Dowden's view of Shakespeare is of "one long study of self-control" (Dowden, 1883: 36) as a consequence of which "by virtue of his very knowledge [...] he comes face to face with the mystery of the unknown. Because he had sent down his plummet farther into the depths than other men, he knew better than others how fathomless for human thought those depths remain" (ibid.: 35).

2. The English Restoration of 1660 , after only eleven years of parliamentary rule, is inevitably somewhat less momentous than the Meiji Restoration of 1868, which ended 265 years of national isolation, as well as abolishing the feudal class system and restoring the 
Emperor as head of state after centuries of military rule. Yet the softening of religious antagonisms in Restoration England allowed for an enlarged role for literary discourse, especially poetry, that may be compared to the development of a national literature in Meiji Japan (1868-1912) spurred by translations of foreign works and language reform.

3. The two academic works were published under Tsubouchi's actual name of Yūzō.

4. The image of "the bottomless lake" probably came from Dowden. See Note 1.

5. Tsubouchi's adoption of strict seven-five syllabic meter (shichigo chō) stands out from the prose format that he otherwise adopts in the same way that Ariel's trochaic tetrameters stand out from the blank verse.

6. The best known line of the work runs shōsetsu no shunō wa ninjō nari setai fūzoku kore ni tsugu (Tsubouchi, 1978 a: 42) [The main concern of the novel is human feelings. The customs and conditions of society are of secondary importance.]

7. An adaptation of the play by Shimamura Hōgetsu, with his partner Matsui Sumako as Cleopatra, was staged in 1914, but despite the parallels mentioned below made little impression compared to their sensational staging of Tolstoy's Resurrection the same year. The first complete production of the play was not until Fukuda Tsuneari directed his own translation in 1969 with Gekidan Kumo.

8. Although Tsubouchi had been a pioneer of psychological realism in his early writings on fiction, he wished to remain apart from the new literary schools of both realism and naturalism that emerged in early twentieth century Japan.

9. Dowden writes that "The transition from the Julius Caesar of Shakspere to his Antony and Cleopatra produces in us the change of pulse and temper experienced in passing from a gallery of antique sculpture to a room splendid with the colours of Titian and Paul Veronese. In the characters of the Julius Casar there is a severity of outline [...] The characters of the Antony and Cleopatra insinuate themselves through the senses, trouble the blood, ensnare the imagination, invade our whole being like colour or like music. The figures dilate to proportions greater than human, and are seen through a golden haze of sensuous splendor." (Dowden, 1883: 306-307)

10. A typical observation that he made in an essay comparing Shakespeare with Chikamatsu and Ibsen (Tsubouchi, 1960: 222).

11. Tsubouchi chooses to translate the abbreviated "I'll" as "I will" rather than "I shall". In performance, the Japanese form could be interpreted as either exclamatory or else whimsically.

\section{References}

Dowden, Edward (1883): Shakspere: A Critical Study of His Mind and Art. London: Kegan Paul Trench \& Co.

Dryden, John (2003): The Major Works. Ed. Keith Walker. Oxford: Oxford University Press. (2011): All for Love. Ed. N.J. Andrew. London: Methuen Drama. First published 1678.

Momose Izumi (2006): Japanese Studies in Shakespeare: Interpreting English Drama Through the Noh and 'Theatrum Mundi'. Lewiston, NY: Edwin Mellen Press.

Moraldo, John C. (2010): "Nishida Kitarō”, Stanford Encylopedia of Philosophy. Available at: <http://plato.stanford.edu/entries/nishida-kitaro/>. Accessed 11 July 2011.

Poole, Adrian (2004): Shakespeare and the Victorians. London: Thomson Learning.

Said, Edward W. (1995): Orientalism: Western Conceptions of the Orient. London: Penguin. 
Satō Isao (1981): Tsubouchi Shōyō ni okeru Doraiden juyō no kenkyū (A Study of the Reception of John Dryden by Tsubouchi Shōyō). Tokyo: Hokuseido Shoten.

Shakespeare (1986): The Oxford Shakespeare: The Complete Works, Stanley Wells and Gary Taylor, eds. Oxford: Oxford University Press.

Shōyō Kyōkai, ed. (1986): Tsubouchi Shōyō jiten (Encyclopedia of Tsubouchi Shōyō Studies). Tokyo: Heibonsha.

Taine, Hippolyte Adolphe (1887): History of English Literature. Trans. Henry van Laun. New York: John R. Alden. First translated 1871.

Tsubouchi Shōyō (trans.) (1934): Anton̄̄ to Kureopatora (Antony and Cleopatra). Tokyo: Chūō Kōron.

- (1960): "Chikamatsu as compared with Shakespeare and Ibsen" (Chikamatsu tai Shēkusupiya tai Ipusen). In Matsumoto Ryōzō, ed., "History and Characteristics of Kabuki: The Japanese Classical Drama", trans. by Shōyō Tsubouchi and Jirō Yamamoto. Yokohama: Heiji Yamagata, 207-39. First published 1909.

- (1977): "Shōtoku taishi to akuma" (Prince Shōtoku and the Demon). In Shōyō Kyōkai, ed., Shōyō senshū, Vol. 3. Tokyo: Daiichi Shobō. 443-501. First published 1935.

- (1978a): Shōsetsu shinzui (The Essence of the Novel). In Shōyō Kyōkai, ed., Shōyō senshū, Appendix 3. Tokyo: Daiichi Shobō, 1-157. First published 1885.

- (1978b): "Soko shirazu no mizuumi" (The Bottomless Lake). In Shōyō Kyōkai, ed., Shōyō senshū, Appendix 4. Tokyo: Daiichi Shobō, 385-392. First published 1891.

Tsubouchi Yūzō (1901): Eibungaku shi (History of English Literature). Tokyo: Waseda University Press.

- (1902): Eishibun hyōshaku (Introduction to English Poetry). Tokyo: Waseda University Press.

Tsuno Kaitarō (2002): Kokkeina kyojin: Tsubouchi Shōyō no yume (The Comic Giant: the Dream of Tsubouchi Shōyō). Tokyo: Heibonsha.

Ueda Atsuko (2007): Concealment of Politics, Politics of Concealment: The Production of 'Literature' in Meiji Japan. Stanford, CA: Stanford University Press. 